\title{
Project Based Learning di Kelas Terjemahan Bahasa Asing untuk Pendidikan Vokasional
}

\author{
Ahmad Muam \\ Prodi Bahasa Inggris Sekolah Vokasi Universitas Gadjah Mada \\ Email: ahmadmuam@ugm.ac.id
}

\begin{abstract}
:
The research aims to identify obstacles and possible challenges in deploying project based learning as learning method for translation course in vocational education. Given that vocational education should shorten the gap between well-equipped skill of graduate with labor market demand, each courses offered are obliged to ensure that skill delivered in the course are practically in line with labor demand and are ready to use, including translation courses. The research adopted qualitative approach and putting case study method completed by interview and survey as method of data collection. The interview was intended to dig the faculty's experience in facilitating translation courses in class within last one year period, particularly on its challenges and obstacles. Meantime, the survey was designed to absorb the learner's perception and opinion towards the advantages of project based learning implementation. The respondent involved in the research are students of English program Vocational College Universitas Gadjah Mada who already taken translation 1 and 2 courses. Next, The data are descriptively presented along with related supporting figures and tables. The research reveals that in the context of vocational education, translation teaching using project based learning offers a lot of advanteges to the students particularly in equipping them with proper undersntading on conceptual knowledge and its practical implementation in work place. However, its implementation hit some obstacles which could be derived as follow 1. Lack or time preparation and length of time to conduct the team project, 2. Lack of lecturer's experience in delivering PBL in class
\end{abstract}

Key words: translation teaching, project-based learning, vocational education

\section{Intisari:}

Penelitian ini bertujuan untuk mengidentifikasi hambatan dan tantangan project-based learning untuk mata kuliah terjemahan dalam pendidikan vokasi. Dengan tuntutan bahwa kemampuan output lulusan pendidikan vokasi tidak terdapat gap yang terlalu jauh dengan kebutuhan pasar kerja, maka setiap pembelajaran (courses) didorong untuk menghasilkan output lulusan dengan skill yang sedekat mungkin linear dan siap pakai, termasuk dalam kemampuan penerjemahan. Penelitian ini menggunakan pendekatan studi kasus dengan metode pengambilan data berupa wawancara dan angket. Wawancara digunakan untuk menggali pengalaman pengajar mata kuliah terjemahan dalam kurun waktu satu tahun terkait tantangan dan hambatan dalam penerapan project based learning dalam proses pembelajaran. Sedangankan angket digunakan untuk mencari tahu pengalaman pembelajaran dari perspektif peserta didik. Responden adalah mahasiswa Program Studi Bahasa Inggris Sekolah Vokasi UGM yang sudah mengambil mata kuliah terjemah 1 dan terjemahan 2. Data akan disajikan secara deskriptif disertai dengan tabel atau grafik penunjang. Penelitian ini menunjukkan bahwa untuk konteks pendidikan vokasional, pengajaran mata kuliah dengan PBL memberikan keuntungan bagi mahasiswa dalam hal penguasaan materi dan aplikasi nyata di dunia kerja. Namun begitu, terdapat hambatan dalam penerepannya yaitu; kurangnya alokasi waktu, kurangnya kualitas persiapan dan kurangnya pengalaman dosen dalam penerapan PBL.

Kata Kunci: pengajaran terjemahan, project-based learning, pendidikan vokasional 


\section{Pendahuluan}

\section{Pendidikan Vokasi}

Kompetensi dan kualifikasi (vokasional) menjadi nyawa atau ruh dari pendidikan vokasional. Kompetensi ini banyak berubah sebagai dampak globalisasi yang membawa iklim knowledge based economy perubahan organisasi kerja yang massif (Maag Merki, 2008). Secara umum kompetensi didefinisikan sebagai knowledge, skill, otoritas dan kemampuan yang dibutuhkan seseorang (Zhao, 2014) kompetensi hanya bisa didapatkan melalui eksplorasi kemampuan sesorang di bagian yang disebut "disposisi kinerja kognitif" (Rauner, 2012). Kompetensi dan kualifikasi ini dikembangkan secara berbeda oleh berbagai Negara termasuk Indonesia yang memetakan kompetensi kerja dengan mengacu pada standar Australia. Kompetensi yang dikembangkan saat ini bisa diklasifikasikan menjadi 3 kelompok ; kompetensi berbasis kerja yang sangat erat hubungannya dengan kurikulum berbasis kompetensi, general personality competence yang berhubungan dengan karakter umum yang dibutuhkan seseorang untuk menyelesaikan pekerjaan seperti kemampuan komunikasi, berfikir sistematis dan diagnostic dan "kompetensi kunci" pada pekerjaan tertentu, dan terakhir kompetensi holistik yang merupakan gabungan dari kedua kompetensi sebelumnya (Hager, 1995). Ketiga jenis kompetensi tersebut membedakan model kurikulum yang digunakan untuk menguasainya semisal contoh kompetensi holistic akhirnya dalam proses pendidikan diterjemahkan sebagai pendidikan vokasional yang holistik. Kurikulum vokasional holistic memungkinkan lulusan untuk memiliki kompetensi okupasi yang applicable di lapangan kerja dan memiliki kemampuan untuk pengembangan diri dari profesinya yang disebut dengan professional competence. Kemudian level dari professional competence ini harus tercermin pada action competence (Reuner, 2010) yang bisa dihasilkan melalui sistem pembelajaran vokasional yang tepat. Dalam bahasa literal, professional competence ini diartikan sebagai kemampuan untuk menyelesaikan pekerjaan, sementara dalam konteks pendidikan vokasional, professional competence lebih kepada output yang diharapkan dari proses pendidikan vokasional yang merangkum 
dan menerapkan kurikulum akademik dan praktik secara tepat (Zhao, 2014). Dalam kajian pendidikan vokasional, istilah kompetensi, intelejensi dan kualifikasi diterjemahkan secara berbeda namun saling terkait.

Dengan tujuan untuk menghasilkan kompetensi dan kualifikasi tertentu, dari proses penyusunan, kurikulum sudah dapat dipisahkan menjadi 3 bentuk (Zhong et al, 2008):

- Kurikulum berorientasi kompetensi: kurikulum ini dianggap sebagai kurikulum yang tradisional

- Kurikulum untuk pengembangan karir jangka panjang : didasarkan pada kebutuhan kerja namun mengalami tantangan seiring berubahnya bentuk dan organisasi kerja dewasa ini

- Kurikulum yang fokus pada hubungan pembelajaran dan kerja : kurikulum yang mensintesiskan pembelajara dan kerja

Pada akhirnya, dari hasil penelitian terkahir oleh Huisinga (2005) dan Xu (2008) terdapat tiga model kurikulum pendidikan vokasi yang berkembang. Ketiga model tersebut dikembangkan dan diterapkan secara berbeda. Model ini adalah hasil pemehaman yang berbeda atas kompetensi, kualifikasi dan proses pembelajaran yang tepat. Model kurikulum tersebut adalah sebagai berikut:

- TPP (theory and practices in parallel): menekankan pada sistematika pengetahuan, fokus pada reproduksi, pemahaman dan verifikasi pemahaman teoritis. Pengajaran yang diselenggarakan fokus pada pelakasanaan kerja operasional teknis dan skill, pembelajaran pada proses kerjanya cenderung kurang diberikan. Kurikulum ini cenderung tidak menempatkan "pekerjaan" sebagai satu entitas yang utuh, pembelajaran fokus pada penanaman pemahaman dan pelatihan, mengesampingkan kemampuan belajar dari masalah yang timbul dan output luluan cenderung kurang bagus dalam hal berfikir secara deduktif

- TSP (theory in the services of practices): kurikulum ini benarbenar tunduk pada pasar. Semua standar kompetensi disusun berdasarkan kebutuhan pekerjaan industri yang ada. Kompetensi 
diajarkan secara top down dan output yang dharapkan adalah perubahan perilaku yang observable pada diri lulusan. Karena tujuan utama adalah memenuhi kompetensi yang sesuai dengan kebutuhan pasar, makan tujuan pendidikan cenderung terkesampingkan di model ini

ITP (integration between theory and practice): kurikulum ini merupakan model yang mencoba menyempurnakan kedua bentuk sebelumnya. Effective learning adalah kemampuan yang ditanamkan pada peserta didik. Effective learning adalah kemampuan siswa untuk mampu belajar dari proses kerja. Tujuan yang diharapkan dari model ini adalah lulusan kerja memiliki knowledge skills, professionl identity dan shaping competence (ketika sudah bekerja). Tujuan kurikulum akhirnya adalah holistic professional competence dengan isi pembelajaran tentang tugas professional dan proses pembelajaran yang mementingkan proses kerja
Jika dipadankan dengan konsep pendidikan lain, ITP yang menjadi model ideal pendidikan vokasional ini kurang lebih sama dengan model experiential (experiential learning). Experiential learning menstimulasi daya kritis mahasiswa untuk menemukan hal baru dan itu tidak ditemukan dari buku dan perkuliahan (Williams, 1983). Sehingga, bisa diartikan bahwa titik tekan dari model pembelajaran ini adalah pengalaman nyata melalui proses pembelajaran (Dedouli 2001). Pengalaman nyata yang akan berguna di dunia kerja ini yang kurang lebih menjadikan ITP dan experiential education pada garis yang sama.

Untuk menjembatani kebutuhan link antara teori dan praktik dalam kebutuhan pendidikan vokasi, maka setelah memilih model pendidikan dan pendekatan kurikulum seperti yang telah disebutkan perlu dipilih metode pembelajaran yang cocok untuk menerjemahkan kebutuhan tersebut. Di Universitas Gadjah Mada, ada beberapa model yang diadopsi seperti student centered learning, problem based learning atau bahkan project based learning yang semuanya 
memiliki kelebihan dan kekurangan dan memiliki kesesuain berbeda terhadap program studi atau mata kuliah yang bervariasi.

\section{Project Based Learning}

Kenapa harus project based learning? Karena ada skill dan kompetensi yang hanya didapatkan dengan mengalami secara langsung, bahkan jika harus di luar kelas. Bukankah ada training untuk lulusan universitas sebelum memulai pekerjaan profesional? Itulah kenapa pendidikan vokasional ada agar gap antara dunia pendidikan dan dunia kerja bisa begitu dekat tanpa harus ada jembatan baru lagi yang harus dibuat. Jika dilihat persyaratan kerja sekarang ini tidak melulu mensyaratkan kemampuan teknis bidang, namun juga berbagai skill yang menjadi turunan dari hubungan kemampuan teknis bidang dan konteks pekerjaan itu sendiri. Sebagai contoh, sebuah iklan lowongan penerjemah. Selain syarat utama excellent knowledge dalam kebahasaan dan fluency dalam proses terjemahan, seorang penerjemah juga diharapkan mampu menyesuaikan gaya penerjemahan sesuai dengan gaya dan guideline editorial, mampu memprioritaskan kebutuhan user dan pasar, mampu merespon dengan professional semua instruksi manajer dan mampu memberikan feedback atau kontribusi kepada penerjemah lain. Semua hal diatas tidak mampu ditampung dengan pembelajaran konvensional di kelas yang contentoriented.

Project based learning bisa menjadi turunan dari model kurikulum ITP yang memiliki semangat pendidikan experiential (experiential education). . Tipe pembelajaran ini menjembatani mahasiswa untuk mengalami langsung dalam proses pendidikan.

"Inti dari project based learning adalah ketika masalah nyata keseharian mampu memantik ketertarikan mahasiswa dan kemudian memicu mereka untuk berfikir untuk memperoleh dan menerapkan pemahaman kognitif mereka untuk pemecahan masalah (David 2008, hal. 81)."

Dalam praktis pelaksanaan, PBL bisa diterapkan pada pembelajaran dalam kelas dan juga di luar kelas.

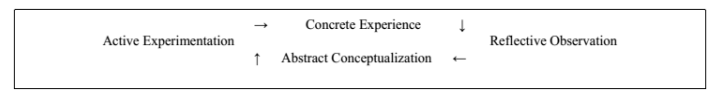

Gambar 1: Model cyclical Kolb (sumber: Efstratia 2014) 
Project based learning menawarkan beberapa kelebihan pun juga kelemahan. Setidaknya ada beberapa kelebihan baik bagi pengajar maupun bagi peserta didik yang terlihat dalam 3 kategori yakni pengembangan kompetensi mahasiswa, kolaborasi antara dosen dan mahasiswa, dan pengembangan profesionalitas dosen (Lasauskine \& Rauduvaite, 2015a). Selanjutnya Lasauskine dan Rauduvaite (2015b) merinci manfaat yang diperoleh dalam setiap kategori tersebut. Dalam kategori pertama, PBL lebih mampu mengembangkan self-dependance mahasiswa dan juga rasa tanggung jawab untuk menyelesaikan satu kegiatan. Di samping itu, dalam kategori ini mahasiswa terpicu untuk mengembangkan kompetensi sosialnya. Kedua, terkait kolaborasi dosen dan mahasiswa, seorang dosen mampu lebih dekat dalam membimbing mahasiswa menyelesaikan proyeknya selain juga akan mendapatkan kepuasan ketika mahasiswa mampu menyelesaikan project karena hasil coachingnya. Terakhir, bagi dosen sendiri, dengan PBL seorang dosen mampu memberikan tugas yang bermakna dan relevan baik dengan materi maupun dengan kebutuhan praktis tempat kerja. Lebih dari itu, perasaan puas dosen akan terpicu dengan melihat proses perbaikan dalam pengajaran dan juga hasil nyata dari setiap projek yang ditugaskan ke mahasiswa.

Satu sisi yang tak terpisah dari kelebihan yang ditawarkan PBL, beberapa kekurangan yang muncul pada proses pembelajaran ini adalah kurang terpantaunya peran individu mahasiswa dalam project team dan juga kemungkinan tidak adanya jiwa kepemimpinan atau bahkan kompetensi social dalam proses belajar mandiri mereka. Selain itu, kompetensi didactic dan manajerial dosen dalam mengawal kerja tim mahasiswa juga cenderung kurang dalam PBL. Bahkan, mungkin juga dosen tidak memiliki kesadaran untuk memberikan pengarahan atau dialog yang cukup sebelum memberikan tugas proyek kepada mahasiswa "(Lasauskine \& Rauduvaite, 2015C)".

Ada tujuh prinsip yang dikemukakan oleh Markhaam (2011) yang harus ditaati dalam penerapan PBL;

1. Mengidentifikasi tantangan Inti dari pembelajaran ini adalah memberikan target yang menantang. Target 
tersebut harus sesuai dengan sasaran pembelajaran. Yang perlu dipastikan adalah bahwa target tersebut realistis, nyata dan berasal dari isu atau masalah yang besar

2. Memberikan pertanyaan pemicu (driving question)

Satu proyek dimulai dengan pemantik yang membuat mahasiswa terpicu untuk menyelesaikan. Dosen harus tahu benar pemahaman seperti apa yang harus dikuasai oleh mahasiswa yang tercermin dari hasil akhir projek mereka

3. Menyusun assessment yang tepat

Hasil akhir dari proses pembelajaran ini adalah hasil akhir maka hasil akhir tersebut harus dinilai berdasarkan kesepakatan penilaian yang telah ditetapkan di awal. Kunci dari penilaian satu projek adalah isi, skill dan kemampuan fikir mahasiswa

4. Merencanakan backwards

Pembelajaran ini selain bertumpu pada hasil akhir juga pada proses. Dosen harus membimbing mahasiswa melalui proses penyelesaian projek mereka. Selain itu, harus dipastikan perilaku mahasiswa dalam berkolaborasi atau memberikan feedback atas hasil karya temannya

5. Mengikuti dan terlibat dalam projek

Pembelajaran ini membutuhkan dosen untuk terlibat sejak awal dalam projek mahasiswa. Dosen bisa membantu dalam menyusun penyelesaian atau terlibat dalam memilih benchmark projek yang akan digunakan mahasiswa

6. Memfasilitasi tim/mahasiswa Dalam projek ini, dosen selain menginisiasi proyek dengan memantik daya kritis juga harus memastikan bahwa proyek yang dilakukan mahasiswa bisa berjalan

7. Memastikan hasil akhir Yang harus dihindari adalah terlalu fokus pada bimbingan penyelesaian projek sehingga 
lupa bahwa penyelesaian proyek berbatas waktu sehingga tidak selesai dengan sempurna. Maka dengan itu, harus dipastikan bahwa hasil akhir adalah tujuan.

Hampir sama dengan Markhaam, Efstratia menyebutkan bahwa model ini akan berjalan dengan baik jika memenuhi 7 syarat (2014b). ketujuh aspek yang menjadi prasyarat keberhasilan PBL mencakup dosen memahami ketertarikan mahasiswa, kemudian mengarahkan dengan pertanyaan yang menstimulasi, mahasiswa diberikan kebebasan untuk memilih referensi dan metode untuk mencapai sasaran yang mereka tetapkan, mahasiswa terdorong untuk berfikir kritis, mampu menggunakan teknologi, adanya umpan balik dan revisi sebelum mahasiswa memberikan atau mempresentasiikan hasil proyeknya ke pengguna.

Project based learning bisa diterapkan dengan berbeda pada mata kuliah, termasuk kuliah terjemahan. Terjemahan yang mana pelakunya disebut penerjemah bisa menjadi satu skill yang terkait dengan satu profesi terntentu. Profesi ini yang menuntut seseorang yang ingin melakukannya untuk menguasai banyak aspek. Di sisi lain, kemampuan menerjemahkan, tidak untuk satu profesi terntentu, menjadi kemampuan dasar mahasiswa sebagai penunjang profesi lainnya. Dengan begitu, project based learning ini menjembatani bagaimana mahasiswa secara mandiri belajar langsung dari proyek terjemahan yang dalam konteks spesifik ketika memilih menjadi penerjemah atau hanya jika ketika mereka harus melakukannya sebagai penunjang profesi mereka.

\section{Pengajaran Kelas Terjemahan}

Dalam pendidikan vokasional yang lebih menekankan pada kemampuan praktik yang berhubungan dengan dunia kerja dibanding kekayaan pengetahuan konseptual, mahasiswa harus mampu menguasai konsep dasar terjemahan dan juga jika diterapkan pada konteks pekerjaan. Dalam kaitan dengan penerjemah sebagai profesi, terdapat beberapa prinsip yang harus difahami oleh mahasiswa yang bisa bermanfaat jika diterapkan pada dunia kerja nantinya. Robinson (2007) menjelaskan seorang penerjemah bisa dilihat dari dua sudut pandang. Pertama, dirinya sebagai professional yang bekerja dengan useroriented approach dan kedua sebagai 
seoang penerjemah yang bertanggung jawab terhadap keilmuannya. Sebagai professional, dia harus membangun citra reliabilitas terhadap dirinya, timeliness pada pengerjaan projek dan penetapan cost atas jasanya. Ketiga hal tersebut tidak termasuk dalam kajian terjemahan namun menjadi penting bagi mahasiswa terkait profesionalitas sebagai penerjemah. Reliabilitas mengajarkan bahwa seorang penerjemah tidak hanya reliable karena terjemahan selalu tepat dalam aspek linguistik dan social budaya namun juga reliable karena kemampuannya dalam memahami kebutuhan pengguna, ketelitian, keramahan dan kemampuanya dalam menjaga kerahasiaan. Kesemuanya bisa diajarkan kepada penerjemah dengan lebih baik dengan pengalaman nyata lewat project based learning, tidak tercukupi dengan pembelajaran konseptual dalam kelas. Selanjutnya, timeliness dan cost mengajarkan mahasiswa untuk pandai menjadwalkan penyelesaian pekerjaan dan berapa cost kompetitif yang harus diberikan. Kedua hal tersebut merupakan refleksi realitas pekerjaan seorang penerjemah. Terakhir adalah trade-off yaitu ketika seorang penerjemah mampu menyesuaikan ketepatan dan kecepatan pekerjaan dengan harga yang harus dibayar oleh pengguna.

Pengalaman lain yang tidak mungkin didapatkan dengan pembelajaran konvensional di dalam kelas adalah pengembangan diri dalam hal intelektual lewat pengalaman langsung. Dalam hal ini Robertson (2013) menjelaskan beberapa proses pengembangan diri yang bisa didapat dengan pengalaman penyelesaian projek langsung. Peningkatan kecerdasan ingatan dalam menyelesaikan pekerjaan terjemahan adalah aspek pertama yang hanya didapatkan dengan banyak berlatih, apalagi dengan berlatih langsung dalam konteks tuntutan pekerjaan professional. Kedua adalah translator learning style, seorang penerjemah akan dengan lancar mengenali dan menyikapi konteks teks yang dia terjemahkan, relevansi dan kemampuan coding dengan banyak latihan atau praktik. Dengan banyak latihan, mahasiswa juga mampu melatih baik representational memory atau procedural memorynya. Ingatan pertama perlu dilatih agar seorang penerjemah mampu mengingat padanan dari kata yang spesifik sementara ingatan kedua 
berkaitan dengan keterampilan analisis, transfer makna dari bahasa sumber ke bahasa tujuan dan juga mencakup kecakapan menulis atau mengetik sembari menerjemahkan. Kesemuanya merupakan kompetensi praktis di luar pembelajaran konseptual yang penting untuk dikuasai mahasiswa.

Singkat kata, project management, reliabilitas dan income penerjemah di atas tidak ditemukan dalam pengajaran terjemah yang hanya pada konteks kebahasaan. Kemampuan atau profesionalitas dalam menyelesaikan pekerjaan berbeda dengan pemahaman konseptual tentang teori penerjemahan. Sementara dalam hal konsep, adanya banyak pendekatan model dan pendekatan dalam penerjemahan sering menimbulkan salah saham atau kontroversi dalam penerjemahan. Elmgrab (2013) menuturkan bahwa mistranslation dan masalah penerjemahan merupakan masalah yang selalu ada sehingga seorang dosen atau instruktur harus berulang kali berkonfrontasi bukan hanya dengan masalah kebahasaan atau batasan social budaya bahasa sumber dan bahasa tujuan namun juga dengan model pengajaran agar sesuai dengan kapasitas mahasiswa. Tugas utama yang sering muncul adalah 1) menjelaskan masalah lingusitik yang ada pada bahasa asal dan 2) menjelaskan strategi penerjemahan yang tepat dari bahasa sumber ke bahasa sasaran. Sehingga dibutuhkan interaksi yang aktif antara dosen dan mahasiswa selama proses penerjemahan (Taylor, 1980).

Selaras dengan yang disampaikan Taylor, terdapat dua kompetensi yang harus dimiliki penerjemah ketika menerjemahkan teks yakni kompetensi linguistic dan kompetensi terjemahan. Kompetensi linguistic dan kompetensi terjemahan harus menjadi konten dari kuliah terjemahan seperti yang tergambar pada diagram di bawah:

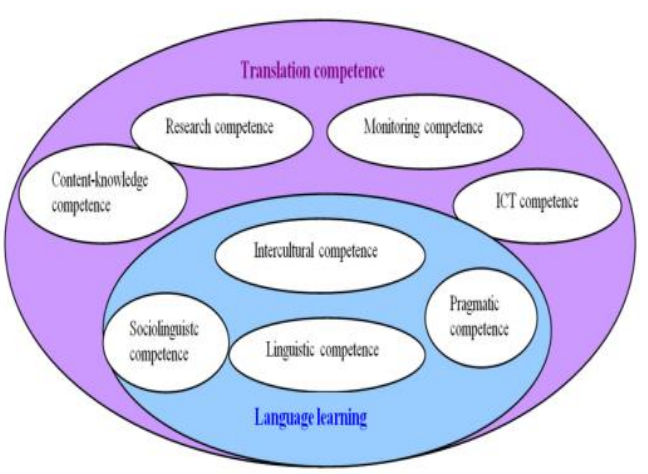

Gambar 2: Tujuan pembelajaran mata kuliah terjemahan (Popescu, 2013)

Sekali lagi terlepas dari kompetensi professional sebagai translator, Secara spesifik dalam proses 
menerjemahkan teks, ada dua kompetensi yang dibedakan; kompetensi linguistic dan kompetensi penerjemahan yang keduanya harus diakomodasi dalam proses pengajaran yang tepat. Berangkat dari dua kebutuhan di atas, maka pengajaran tejemahan untuk kebutuhan pendidikan vokasional bertumpu pada dua hal secara bersamaan; aspek pedagogis dan aspek methodologis. Aspek pedagogis adalah bagaimana seorang dosen berperan sebagai coach yang senantiasa membimbing, memberikan feedback dan menjadikan feedback menjedai pengetahuan baru yang digunakan bahan evaluasi bersama. Dari aspek methodologis, model pengajaran adalah yang menyediakan kesempatan mahasiswa mengalami langsung bagaimana menerjemahkan dengan proses di bawah bimbingan dosen.

Terakhir, karena proses pengajaran terjemah yang ideal mencakup pengetahuan konspetual tentang terjemahan dan pengembangan kemampuan praktis dalam menyelesaikan pekerjaan terjemahan maka dibutuhhkan seperangkat assessment yang tidak hanya fokus pada aspek kognitif saja. Kemudian, Error

jembatan untuk menggabungkan antara teori terjemahan dan kontekks pengajaran. Lewat error analysis ini bisa terlihat efisien dan ketidak efisienan proses pengajaran yang dilakukan. Dengan assessment ini bisa dilihat juga performa individu atau grup terkait kemapuan dalam level konsep dan level penyelesaian pekerjaan.

\section{Metodologi Penelitian}

Penelitian ini untuk mengumpulkan perspektif dosen dan mahasiswa terhadap penerapan project based learning di kelas terjemahan. Kemudian, untuk mencari tahu dampak positif dan tantangan yang dihadapi dalam penerapan metode pembelajaran tersebut. Pendekatan kuantitaif digunakan kuesioner yang disebarkan kepada 99 mahasiswa semester 4 dari 3 kelas berbeda yang sudah mengambil kelas terjemah 1 di semester 3 dan terjemah 2 di semester 4 program studi Bahasa Inggris Sekolah Vokasi Universitas Gadjah Mada. Responden diminta mengisi kuesioner lewat google form yang menggali pengalaman belajar kelas terjemahan dengan menggunakan project based learning. Kelas terjemahan 1 dan 2 diampu oleh dosen berbeda. 
Mahasiswa boleh mengisi kuesioner berdasarkan pengalaman di salah satu kelas yang menerapkan project based learning. Kuesioner terkait project based learning sebanyak 6 item, kuesioner tentang pembelajaran kolaboratif 6 item. Dari 99 mahasiswa yang menjadi target responden, respon rate atau yang mengisi dan mengembalikan formulir secara penuh bejumlah 60 mahasiswa.

Selanjutnya, in-depth interview juga dilakukan kepada dosen pengajar untuk mendapatkan pengalaman penerapan model belajar project based translation. Pendekatan ini merupakan salah satu metode kualitatif yang digunakan. Selain interview, analisis juga dilakukan pada hasil kerja projek mahasiswa sebagai pelengkap. Data akan disajikan secara statistik deskriptif dengan menggunakan tabel sebagai pendukung.

\section{Temuan Penelitian dan diskusi}

Mata kuliah terjemahan di Program Studi Bahasa Inggris Sekolah Vokasi UGM diberikan dua kali yaitu terjemahan 1 di semester 3 dan terjemahan 2 di semester 4. Masing masing mata kuliah memiliki bobot 2 sks yang setara dengan 150 menit kegiatan yang 100 menit darinya digunakan untuk tatap muka di kelas sementara 50 menit sisanya biasanya digunakan untuk penugasan. Mata kuliah terjemahan 1 menekankan pada penguasaan konsep konsep dasar terjemahan sementara yang selanjutnya yang kedua membekali mahasiswa dengan masalah masalah teoritis dan praktis. Dari pembedaan tujuan tersebut terlihat bahwa pada mata kuliah terjemahan lanjutan, mahasiswa baru bisa bersentuhan dengan masalah tekstual terjemahan dan memungkinkan untuk di bawa pengalaman nyata terjemahan di dunia kerja. Sehingga, pada mata kuliah lanjutan ini PBL bisa diterapkan.

PBL menjadi bagian dari kelas terjemahan 2. Kelas terdiri dari 14 kali pertemuan yang yang dibagi dua oleh ujian mid semester. Secara praktis mahasiswa melakukan projek setelah mid semester. Tujuh pertemuan sebelum mid semester digunakan untuk mengenalkan masalah terjemahan baik dalam level konseptual maupun level projek. Pada pertemuan pertemuan awal ini juga, mahasiswa dipantik untuk memilih isu dan merancang projek mereka sendiri. Mahasiswa harus melakukan proses layanan terjemahan kepada pengguna nyata secara langsung dengan batas 
halaman yang disepakati bersama di kelas. Sehingga, learning goals dan planning disusun pada tahap ini dan disesuaikan dengan projek yang harus diselesaikan mahasiswa. Pada tahap awal ini juga, disepakati indikator dan aspek aspek yang digunakan untuk penilaian dan juga aturan dalam penyelesaian projek. Indikator yang disusun bukan hanya indikator hasil akhir produk namun juga indikator proses; bagaimana mereka menyelesaikan pekerjaan termasuk bagaimana mereka berhubungan dengan pengguna jasa mereka.

Karena proyek diselesaikan dalam kelompok, maka indikator proses juga mencakup rincian tugas dan peran individu dalam kelompok. Setiap kelompok juga harus merekam dalam log book cara kerja mereka termasuk referensi dan proses bagaimana mereka menyelesaikan proyekt, selain memberikan laporan project dalam bentuk jadi dan penjelasan dari metode terjemahan yang digunakan. Assessment dari dosen dan tim lain (intergroup assesment) diberikan sebelum hasil diserahkan kepada pengguna. Terkahir, feedback diberikan oleh pengguna produk.
Dari hasil wawancara dengan dosen, dalam kelas terjemahan, secara umum didapatkan fakta bahwa mahasiswa lebih mampu menjadikan pembelajaran sebagai proses individual yang memungkinkan mahasiswa untuk memilih tantangan untuk projeknya dan mengatur pressure dalam penyelesaian projek mereka sendiri. Kemudian, karena kerja individu mereka "mahasiswa lebih termotivasi untuk menyelesaikan projek yang dia pilih" dan "mahasiswa lebih mampu mengembangkan kretaivitas dalam penerjemahan". Menurut dosen pengajar, secara umum "mahasiswa dipaksa mampu untuk menjelaskan proses dari hasil projeknya”. Dalam hal ini mahasiswa selain harus menyediakan hasil akhir terjemahan yang mampu dikaji dan dibandingkan, mereka juga dipaksa mampu memberikan penjelasan secara konseptual dari proses penerjemahan yang telah mereka lakukan. Dengan kata lain, PBL ini memfasilitasi mahasiswa untuk memehamai konsep dan teori dan kemudian mengaplikasikan konsep terebut menjadi hasil nyata dalam lingkungan seperti lingkungan kerja. Dalam kaitan bagaimana mahasiswa menghubungkan kajian teoritis dengan aplikasinya dalam project, akan banyak 
variasi hasil antara satu tim dengan yang lain yang kemudian saling melengkapi dalam proses diskusi akhir kelas.

Untuk mendapatkan gambaran secara lebih lengkap, tabel dibawah ini menunjukkan respon dari mahasiswa terhadap cara belajar kelas terjemahan dengan menggunakan project based learning.

\begin{tabular}{|l|l|l|l|l|l|}
\hline No. & Statement & $\begin{array}{l}\text { Sangat } \\
\text { Tidak } \\
\text { Setuiu }\end{array}$ & $\begin{array}{l}\text { Tidak } \\
\text { Setuju }\end{array}$ & Setuju & $\begin{array}{l}\text { Sangat } \\
\text { Setuju }\end{array}$ \\
\hline 1 & $\begin{array}{l}\text { Mengerjakan tugas } \\
\text { kelompok lebih baik } \\
\text { daripada tugas individu }\end{array}$ & $3 \%$ & $2.1 \%$ & $43.8 \%$ & $51.1 \%$ \\
\hline 2 & $\begin{array}{l}\text { Melakukan project } \\
\text { nyata yang } \\
\text { berhubungan dengan } \\
\text { pengguna secara } \\
\text { langsung memberikan } \\
\text { pengetahuan dan } \\
\text { pengalaman keria }\end{array}$ & - & $2.9 \%$ & $51.7 \%$ & $45.4 \%$ \\
\hline 3 & $\begin{array}{l}\text { Group project melatih } \\
\text { mahasiswa dalam } \\
\text { critical thinking dan } \\
\text { problem solving }\end{array}$ & - & $10.2 \%$ & $48.3 \%$ & $41.5 \%$ \\
\hline 4 & $\begin{array}{l}\text { Hasil dari projek } \\
\text { kelompok } \\
\text { mencerminkan } \\
\text { kemampuan kosneptual } \\
\text { dan skill yang } \\
\text { berhubungan dengan } \\
\text { dunia keria }\end{array}$ & - & $19.9 \%$ & $44.9 \%$ & $35.2 \%$ \\
\hline 5 & $\begin{array}{l}\text { Group Project } \\
\text { memotivasi mahasiswa } \\
\text { untuk belaiar }\end{array}$ & $8.5 \%$ & $43.7 \%$ & $27.6 \%$ & $20.2 \%$ \\
\hline 6 & $\begin{array}{l}\text { Group project } \\
\text { meningkatkan } \\
\text { kemampuan } \\
\text { terjemahan secara } \\
\text { keseluruhan }\end{array}$ & - & $22 \%$ & $34.5 \%$ & $43.5 \%$ \\
\hline
\end{tabular}

Tabel 1: Respon mahasiswa terhadap proyek kelompok PBL di kelas terjemahan

Item 1 menunjukkan bahwa 94.9\% merasakan manfaat dari group project. Proyek tersebut memberikan manfaat lebih bagi tiap individu dalam tim dibanding ketika masing masing mengerjakan tugas secara individu. Bell (2010) menuturkan bahwa kerja kelompok akan menimbulkan peer pressure diantara anggota tim selama proses belajar yang kemudian mendorong mereka untuk menyelesaikan kemampuan mereka. Akhirnya, mereka bekerja secara dinamis dan masing masing berusaha untuk mencapai sasaran bersama. Karena timbulnya tanggun jawab ini, akan muncul motivasi dalam diri mahasiswa untuk belajar lebih yang di item 2 ditunjukkan dengan angka 27.6\% dan 20.2\%. selanjutnya, motivasi untuk belajar itulah yang menggerakkan kemauan dan kembali lagi memicu mereka untuk menyelesaikan projeknya. Dengan motivasi yang tinggi sebenarnya mahasiswa akan berkurang perasaan terbebani untuk menyelsaiakn project dan atas tambahan jam belajar yang harus mereka penuhi di luar kelas (Dopplet, 2013).

Di item 3, dengan adanya projek kelompok mandiri sebagai bagian dari project based learning, 48,3\% merasa bahwa itu dapat memicu daya kritis dan kemampuan pemecahan masalah mereka, bahkan 41,5\% sangat setuju dengan fakta tersebut. Bell (2010b) mengungkapkan bahwa selain group project juga mampu meningkatkan pemahaman mahasiswa atas materi 
seperti yang ditunjukkan angka 34,5\% dan 43,5\% di item 6, kerja kelompok juga mampu mendorong mahasiswa untuk berfikir kritis dan memiliki kemampuan problem solving yang baik. Selanjutnya, $51,7 \%$ dari responden setuju dan 45,4\% sangat setuju jika group project yang melibatkan pengguna nyata mampu memberikan pengetahuan dan pengalaman baru tentang dunia kerja termasuk problem solving. Tretten dan Zachariou (1997) menuturkan dengan berlatih mencari solusi pada tugas proyek yang serupa dengan tugas di dunia kerja nyata, mahasiswa akan mengerjakannya dan kemudian proses menjadi work habit di samping menjadi terbiasa untuk menggunakan daya pikir kritis untuk problem solving. Sekali lagi Bell (2010C) menekankan bahwa salah satu kemampuan abad 21 adalah social learning yang meliputi komunikasi, negosiasi, dan kolaborasi yang ketiganya akan bisa dimunculkan dengan baik jika mahasiswa dihadapkan langsung dengan praktik di dunia kerja. Terakhir, sebagai konsekuensinya ketika mahasiswa mampu merasakan peningkatan kemampuan dalam praktik terjemahan dan pengalaman langsung dengan dunia nyata , terdapat $44,9 \%$ dan $35,2 \%$ yang merasa bahwa hasil akhir projek mereka sudah benar benar mencerminkan pengetahuan mereka dan apa yang mampu mereka berikan dalam kaitanya dengan dunia kerja nyata.

\begin{tabular}{|l|l|l|l|l|l|}
\hline No. & \multicolumn{1}{|c|}{ Statement } & $\begin{array}{c}\text { Sangat } \\
\text { tidak setuiu }\end{array}$ & $\begin{array}{c}\text { Tidak } \\
\text { setuju }\end{array}$ & Setuju & $\begin{array}{c}\text { Sangat } \\
\text { setuiu }\end{array}$ \\
\hline 1 & $\begin{array}{l}\text { Saya mengembangkan skill } \\
\text { kerja dengan berhubungan } \\
\text { langsung dengan client }\end{array}$ & - & $4.5 \%$ & $55.6 \%$ & $39.9 \%$ \\
\hline 2 & $\begin{array}{l}\text { Saya mampu bersikap } \\
\text { perseptif dan adaptif } \\
\text { terhadap apa yang } \\
\text { dibutuhkan client }\end{array}$ & - & $3.5 \%$ & $67.6 \%$ & $28.9 \%$ \\
\hline 3 & $\begin{array}{l}\text { Saya mampu } \\
\text { meningkatkan kemampuan } \\
\text { reliabilitas saya terkait teks } \\
\text { vang sava hasilkan }\end{array}$ & - & $23.6 \%$ & $33.4 \%$ & $43 \%$ \\
\hline 4 & $\begin{array}{l}\text { Saya mampu menentukan } \\
\text { time frame pekerjaan } \\
\text { teriemahan sava }\end{array}$ & - & $11.3 \%$ & $68.2 \%$ & $20.5 \%$ \\
\hline 5 & $\begin{array}{l}\text { Saya mampu melatih sense } \\
\text { of self-worth dari jasa yang } \\
\text { sava berikan }\end{array}$ & - & $44 \%$ & $35.5 \%$ & $30.5 \%$ \\
\hline 6 & $\begin{array}{l}\text { Secara umum, saya belajar } \\
\text { memberikan jasa } \\
\text { terjemahan secara } \\
\text { professional }\end{array}$ & - & - & $77.5 \%$ & $32.5 \%$ \\
\hline
\end{tabular}

Tabel 2: Respon Mahasiswa Terhadap PBL dan Peningkatan Pembelajaran Nyata

Bagaimana PBL membantu mahasiswa untuk cepat mengenal dunia kerja terlihat di tabel 2. Pada item 1 55,6\% setuju bahwa dengan PBL mereka mampu mengembangkan skill yang dibutuhkan untuk kerja ketika lulus sementara $39.9 \%$ dengan lebih yakin merasakan hal yang sama. Salah satu sikap yang bisa dikembangkan melalui PBL adalah sikap perseptif dan adaptif ketika berkaitan dengan kebutuhan pelanggan, setidaknya seperti yang terlihat di item 2, $67.6 \%$ dan $28.9 \%$ responden merasakan hal itu. Blumenfeld (1991) menuturkan bahwa PBL memang Jurnal Lingua Aplicata Volume 1, Nomor 1 September 2017 
dirancang untuk meniru dunia kerja nyata di luar bangku kuliah yang akhirnya memaksa mahasiswa untuk memenuhi tuntutan skill yang dibutuhkan.

Dalam kaitannya dengan kebutuhan skill professional terjemahan, 33,4\% merasa bahwa mereka yakin dengan hasil pekerjaannya dan yakin bahwa itu reliable di mata pengguna/client. Dalam aspek ini, mahasiswa belajar untuk memperhatikan detail dari keinginan client, keluesan untuk menerjemahkan jenis teks yang berbeda, friendliness terhadap pengguna dan juga kemampuan untuk menjaga kerahasiaan teks. Kemudian, Item 4 menunjukkan bahwa, dengan batasan waktu pekerjaan yang dijanjikan ke pelanggan dan juga alokasi waktu penyelesaian projek kelas, 68,2 \% mahasiswa merasa mereka berlatih untuk menentukan kemampuan penyelesaian pekerjaan mereka sementara $20.5 \%$ yang lain merasa hal yang sama. Sedikit berbeda bagi mahasiswa dalam menghargai pekerjaan mereka sendiri, 44\% merasa bahwa mereka belum mampu menentukan harga bagi pengguna atas jasa yang diberikan sementara $33.5 \%$ merasa sudah memberikan harga sesuai kualitas produk akhir yang diberikan dan 30.5\% yang lain merasa sudah memiliki sense of selfworth. Terakhir, terkait keseluruhan kualitas kerja dan hasil akhir yang diberikan kepada pengguna, 77,5\% merasa bahwa mereka belajar hal baru terkait terjemahan secara professional dengan langsung berhubungan dengan dunia nyata dan sisanya $32.5 \%$ merasa lebih yakin atas hal itu.

Sementara itu, dari sudut pandang dosen pengampu ada beberepa hal yang menjadi hambatan kesuksesan. Pertama, Waktu persiapan mahasiswa yang kurang menjadi alasan utama yang menghambat penerapan PBL dengan baik. Kelas yang terdiri dari 14 pertemuan dan masih harus diisi dengan persiapan materi membuat persiapan mahasiswa untuk merencanakan projek kurang optimal. Mahasiswa biasanya mencari jasa terjemahan yang membuka outsourcing atau membuka jasa penerjemahan mandiri. Dalam hal ini, tidak ada jaminan bahwa satu tim akan mendapatkan pengguna/client dalam waktu yang dialokasikan. Selain itu, diskusi seharusnya menjadi titik kritis dalam pembelajaran ini. Berbagi masalah dan bimbingan dari dosen membutuhkan waktu yang mestinya lebih dari 7 kali 
tatap muka setelah paruh semester. Kedua, alokasi waktu yang pendek. Alokasi waktu adalah mulai dari pertengahan kelas sampai dengan akhir semester. Lamanya penyelesaian projek mulai dari perencanaan, sampai assessment bersama atas projek akhir dalam rentang waktu kurang dari dua bulan sangat tidak efektif. Dikatakan bahwa perencanaan projek bisa dimulai dari awal perkuliahan atau pertemuan pertama. Namun, hal itu membutuhkan koordinasi dengan dosen pengampu mata kuliah terjemahan 1 terkait materi yang harus dimantapkan sebelum mengambil mata kuliah terjemahan 2 . Kemudian inti masalah adalah tidak ada jaminan dosen antar pengampu akan selalu memberikan materi yang linera dan kesepakatan yang baku untuk bersama mendukung PBL.

Selain itu, variasi kemampuan individu mahasiswa harus disikapi dengan hati hati sebelum memulai projek. Namun begitu, dari kesemuanya, satu faktor penting yang menjadi penghambat adalah kurangnya pengalaman dosen dalam menerapkan PBL. Dalam proses ini, dosen yang berperan sebagai coach dan fasilitator harus benar benar terlibat mulai dari proses perencaaan dengan membantu mahasiswa menginisiasi ide, proses pengerjaan dengan memfasilitasi bagaimana mahasiswa bisa mendapatkan kesempatan untuk mempraktekan kemampuannya langsung, dan juga evaluasi dengan membandingkan dengan pengalaman professional dosen sendiri dan konsep dari buku. Dari interview disimpulkan bahwa proses peningkatan bersama sama dengan mahasiswa dalam kelas PBL sangat bisa dilakukan jika dosen memiliki waktu yang lebih banyak terkait pengembangan diri.

Namun begitu, dari kelemahan dosen tersebut ada beberapa dampak positif yang justru terlihat. Pertama, Mahasiswa mampu menginisiasi problem solving dalam projek mereka, merancang manajemen penyelesaian dan tanpa sadar sudah mencurahkan waktu di luar kelas yang lebih untuk mendapatkan hasil akhir projek yang memuaskan. Kurangnya waktu bimbingan memaksa mahasiswa untuk benar-benar mandiri.

Dengan begitu, Dari pendekatan penelitian kualitatif ini tampak bahwa PBL bisa berjalan kurang optimal jika variasi kemampuan individu mahasiswa sejak awal tidak dipetakan baik. Pemetaan ini kemudian menjadi dasar untuk perencanaan pembelajaran. Hal ini 
berhubungan dengan ragam kemampuan individu dalam satu tim projek dan kemampuan tim itu sendiri dengan proyek kegiatan yang dipilih. Intensitas diskusi antara dosen dengan mahasiswa juga menentukan kesuksesan projek. Tidak hanya pada tahap awal dan proses penyelesaian namun juga feedback atas projek yang sudah jadi.

\section{Kesimpulan}

Secara umum, PBL memberikan dampak positif bagi mahasiswa di kelas terjemahan. Dengan project based learning, banyak manfaat yang dirasakan dari proses tersebut yang memang sering berbentuk collaborative learning. Sementara itu, di satu sisi, praktik ini juga memberikan pintu bagi mahasiswa untuk mencicipi pengalaman nyata meliputi tantangan dan kebutuhan dalam projek terjemahan. Namun begitu, dari sisi pelaksanaan, ada beberapa isu yang muncul yang dianggap menghambat kesuksesan model belajar ini. Isu tersebut meliputi alokasi waktu yang kurang termasuk masa persiapan bagi mahasiswa dan dosen untuk menyusun proyek yang akhirnya berdampak pada kualitas. Kemudian, minimnya pengalaman dosen dalam menerapkan model pembelajaran ini disertai tidak meratanya kemampuan masing masing mahasiswa. Singkatnya, Strategi dan model penerapan project based learning harus disesuaikan dengan alokasi jam belajar dan kemampuan mahasiswa yang berbeda. Perilaku dosen sendiri terkait tugasnya untuk terlibat dalam pelaksanaan project based learning dari awal sampai akhir pembelajaran juga perlu ditingkatkan, memperbaiki pola kolaborasi antar mahasiswa dan intensitas interaksi antara mahasiswa dan dosen. Selain itu, pembekalan pengetahuan tentang mekanisme terkait project based learning juga harus dipastikan sudah disampaikan secara menyeluruh di awal kelas.

\section{Daftar Pustaka}

Bell,S. (2010) Project-based learning for he $21^{\text {st }}$ century : skills for the future. The Clearing House. 83, 39-43

David,J.L (2008). What research says about/project-based learning. Educational leadership teaching students to think. 65,5 80-82

Dedouli , M (2001) Experiential learning possibilities of development through the framework of flexible zone. Inspection of educational subject 12, 6 3-8

Doppelt, Y (2003) Impementation and assessment of PBL in a flexible environment. International Journal Of Technology And Design Education. 13, 255-72

Efstratia,D. (2014) Experiential education through project based learning. 
Procedia- social and behavioral sciences 152 p 1256-1260

Elmgrab ,R.A (2013) implication for translation teaching pedagogy: a case of bengazi University: Akdeniz language studies conferene 2012: Procedia- social and behavioral sciences 70 358-369

Hager , P . 1995. Competency standards- a help or a hindrance ? Australian perspective. The vocational aspect of education 47 (141-151)

Husinga (2005) Curricullumforschung. Pp 350-361 Biefeld : Bertelsman

Lasauskine, J\& Rauduvaite, A. (2015) Project based learning at university : teaching experiences of lecturers. Procedia- Social Behavior and sciences 197 (2015) 788- 792

Maag. M . 2008 . Cross-Curricular Competencies . Handbook Of Technical And Vocational Education And Training Research. Dordecht : Springer

Markhaam, T. (2011) Project based learning. Teacher librarian 39:2 38-42

Popescu, T (2013) Developing English linguistic student's translation competence through the language learning process; 3th world conference on learning, teaching and educational leadership-WLCTA 2012. Procedia-social and behavorial sciences 93 p 1075-1079

Reuner F. 2010. Costs, benefits and quality of Apprenticeships .London: Springer

Robinson, D (2007) Becoming a translator: an introduction to the theory and practice of translation. Second edition. London : routlegde

Taylor , B. (1980) Adult language learning strategies and their pedagogical implication; for teachers and teacher' trainees. In croft $\mathrm{K}$ (ed), reading on English as second language (144-152)

Tretten,R \& Zachariou,P (1995) Learning about project based learning : assessment of project based learning in Tinkertech School. San Rafael. California: The autodesk Foundation

Williams, L (1986) Teaching for the two sided mind. A guide to the right /left mind education New York : Simons and Schuster

Zhao, Zhiqun \& Runer, Felix . 2014. Areas of Vocational Education Research. Berlin : Springer-Verlag

Zhao , Z . 208. Development of Competency Learning in Building Automation in China (pp 247-257) Rostock : pitbus 